\title{
Synergistic Chondroprotective Effect of $\alpha$-Tocopherol, Ascorbic Acid, and Selenium as well as Glucosamine and Chondroitin on Oxidant Induced Cell Death and Inhibition of Matrix Metalloproteinase-3 - Studies in Cultured Chondrocytes
}

\author{
Anne-Christin Graeser ${ }^{1, \dagger}$, Katrin Giller ${ }^{1, \dagger}$, Heike Wiegand ${ }^{1}$, Luca Barella ${ }^{2}$, \\ Christine Boesch-Saadatmandi ${ }^{1}$ and Gerald Rimbach ${ }^{1, *}$
}

1 Institute of Human Nutrition and Food Science, Christian Albrechts University of Kiel, HermannRodewald-Strasse 6, Kiel 24098, Germany; E-Mails: graeser@foodsci.uni-kiel.de (A.-C.G.); giller@foodsci.uni-kiel.de (K.G.); wiegand@foodsci.uni-kiel.de (H.W.); ch.boesch@foodsci.unikiel.de (C.B.-S.)

2 Bayer Consumer Care AG, Basel, Switzerland; E-Mail: luca.barella.lb@bayer.ch (L.B.)

$\dagger$ These authors contributed equally to this work.

* Author to whom correspondence should be addressed; E-Mail: rimbach@foodsci.uni-kiel.de.

Received: 1 December 2009; in revised form: 16 December 2009 / Accepted: 23 December 2009 / Published: 24 December 2009

Abstract: Overproduction of reactive oxygen species and impaired antioxidant defence accompanied by chronic inflammatory processes may impair joint health. Pro-inflammatory cytokines such as interleukin-1 $($ IL-1 $\beta$ ) and tumor necrosis factor alpha (TNF- $\alpha$ ) stimulate the expression of metalloproteinases which degrade the extracellular matrix. Little is known regarding the potential synergistic effects of natural compounds such as $\alpha$-tocopherol ( $\alpha$-toc), ascorbic acid (AA) and selenium (Se) on oxidant induced cell death. Furthermore studies regarding the metalloproteinase-3 inhibitory activity of glucosamine sulfate (GS) and chondroitin sulfate (CS) are scarce. Therefore we have studied the effect of $\alpha$-toc $(0.1-2.5 \mu \mathrm{mol} / \mathrm{L})$, AA $(10-50 \mu \mathrm{mol} / \mathrm{L})$ and $\mathrm{Se}(1-50 \mathrm{nmol} / \mathrm{L})$ on $t$-butyl hydroperoxide ( $t$-BHP, 100-500 $\mu \mathrm{mol} / \mathrm{L}$ )-induced cell death in SW1353 chondrocytes. Furthermore we have determined the effect of GS and CS alone (100-500 $\mu \mathrm{mol} / \mathrm{L}$ each) and in combination on MMP3 mRNA levels and MMP3 secretion in IL-1 $\beta$ stimulated chondrocytes. A combination of $\alpha$-toc, AA, and Se was more potent in counteracting $t$-BHP-induced cytotoxicity as compared to the single compounds. Similarly 
a combination of CS and GS was more effective in inhibiting MMP3 gene expression and secretion than the single components. The inhibition of MMP3 secretion due to GS plus CS was accompanied by a decrease in TNF- $\alpha$ production. Combining natural compounds such as $\alpha$-toc, AA, and Se as well as GS and CS seems to be a promising strategy to combat oxidative stress and cytokine induced matrix degradation in chondrocytes.

Keywords: tocopherol; ascorbic acid; selenium; chondroitin; glucosamine; chondrocytes; oxidative stress; inflammation; metalloproteinases

\section{Introduction}

Degenerative joint disorders including osteoarthritis (OA) and rheumatoid arthritis (RA) are characterized by an imbalance in the oxidant/antioxidant homeostasis resulting in oxidative stress, chronic inflammation, metalloproteinase activation and matrix destruction [1]. There is some evidence in the literature [2-4] for a beneficial role of antioxidant micronutrients on clinical symptoms of OA and RA.

It has been shown that arthritis patients may exhibit decreased plasma $\alpha$-toc levels and lower activity of the seleno-protein glutathione peroxidase (GSHPx) as compared to healthy control subjects [5]. Furthermore, a positive association between vitamin E consumption and joint health in humans has been recently reported [6]. However, litte is known about potential synergistic interactions of antioxidants including $\alpha$-toc, AA and $\mathrm{Se}$ on arthritis prevention. Although the potential anti-inflammatory and metalloproteinase-3 inhibitory activity of glucosamine sulfate (GS) and chondroitin sulfate (CS) has been studied using the single compounds per se [7-9], their combination has not been systematically investigated in cultured cells. Thus, it is largely unclear if and in what extent a combination of GS and CS may affect MMP3 in chondrocytes. The aims of this study were twofold: First we have systematically determined the potential synergistic effect of $\alpha$-toc, AA and Se on oxidant induced cell death in SW1353 chondrocytes. Secondly, we have investigated whether there is a synergistic inhibitory activity of GS and CS on MMP3 levels in chondrocytes stimulated with the pro-inflammatory cytokine interleukin-1 $\beta$ (IL-1 $\beta$ ).

\section{Results and Discussion}

\subsection{Potential cytotoxic effects of the test substances and IL-1 $\beta$}

To assure that glucosamine and chondroitin do not affect cell viability, cells were incubated with increasing concentrations of the test substances. As shown in Figure 1, cell viability of SW1353 cells was not significantly impaired up to a concentration of $1,000 \mu \mathrm{mol} / \mathrm{L}$ GS and CS, respectively. For all further experiments concentrations of 100 and $500 \mu \mathrm{mol} / \mathrm{L}$ of GS or CS were chosen. IL-1 $\beta$ was not cytotoxic up to a concentration of $100 \mathrm{ng} / \mathrm{mL}$ (data not shown). 
Figure 1. Effect of glucosamine and chondroitin on cell viability in SW1353 cells. Cells were treated with increasing concentrations of test substances for $24 \mathrm{~h}$. The test compounds did not impair cell viability at any of the concentrations tested. Cytotoxicity was determined by the neutral red assay and cell viability is expressed as percentage of control (untreated cells).

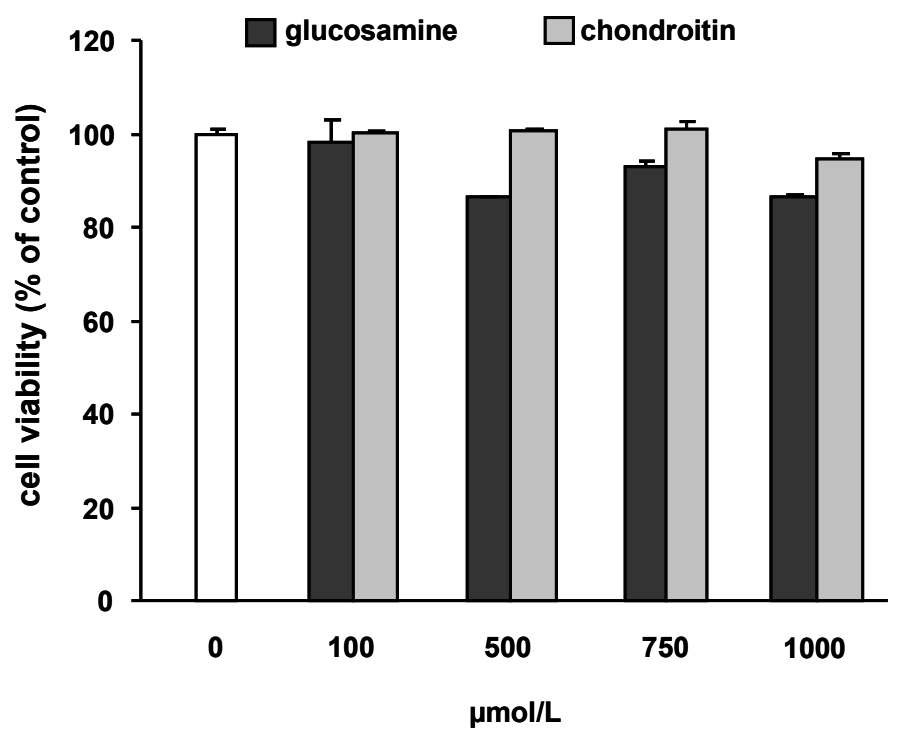

\subsection{Effects of $\alpha$-tocopherol, ascorbic acid and selenium on tert-butyl hydroperoxide induced cell death}

Treatment of SW1353 cells with increasing concentrations of $t$-BHP dose-dependently decreased cell viability, as summarized in Table 1 . Pre-treatment of SW1353 cells with $\alpha$-toc, AA, and Se partly counteracted $t$-BHP induced cytotoxicity. Importantly, a combination of $\alpha$-toc, AA, and Se was more potent in counteracting $t$-BHP induced cytotoxicity as compared to the single treatment with either of these micronutrients. Even at concentrations where the single component did not improve cell viability the combination of $0.1 \mu \mathrm{mol} / \mathrm{L} \alpha$-toc, $10 \mu \mathrm{mol} / \mathrm{L}$ AA and $1 \mathrm{nmol} / \mathrm{L}$ Se was effective in partly preventing $t$-BHP-induced cell death (Figure 2).

While $500 \mu \mathrm{mol} / \mathrm{L} t$-BHP resulted in $70 \%$ cell death of SW1353 cells, the combination of $2.5 \mu \mathrm{mol} / \mathrm{L} \alpha$-toc, $50 \mu \mathrm{mol} / \mathrm{L}$ AA and $50 \mathrm{nmol} / \mathrm{L}$ Se completely prevented t-BHP induced cytotoxicity (Table 1).

The generation of reactive oxygen species is an important factor in the development of human osteoarthritis. In fact, reactive oxygen species may damage lipids, proteins, and matrix components of chondrocytes [10]. Our data clearly indicate that a combination of $\alpha$-tocopherol, ascorbic acid and selenium is more efficient in counteracting oxidant induced cell death than the single compounds per se. The radical scavenging activity of $\alpha$-toc is exerted through its phenolic hydroxyl group which readily donates a hydrogen to peroxyl radicals, resulting in the formation of stable lipid species [11]. Alpha-tocopherol becomes a relatively unreactive free radical as the unpaired electron becomes delocalized into the aromatic ring. The synergistic effect between AA and $\alpha$-toc, as observed in our study in chondrocytes, may be mediated by the matter of fact that the vitamin E radical is efficiently reduced from its free radical form due to AA that can directly regenerate the tocopheroxyl radical back to tocopherol [12]. 
Thus, in oxidant challenged chondrocytes, $\alpha$-toc and AA act synergistically to keep the steady state concentration of $\alpha$-toc high. Thereby a loss of consumption of vitamin $\mathrm{E}$ is significantly prevented.

Figure 2. Effect of $\alpha$-tocopherol, ascorbic acid, selenium, and their combination on cell viability in SW1353 cells after challenge with tBHP. Cells were treated with $\alpha$-tocopherol $(0.1 \mu \mathrm{mol} / \mathrm{L})$, ascorbic acid $(10 \mathrm{mmol} / \mathrm{L})$, selenium $(1 \mathrm{nmol} / \mathrm{L})$, and a combination of all three test compounds $(0.1 \mu \mathrm{mol} / \mathrm{L} \alpha$-tocopherol, $10 \mu \mathrm{mol} / \mathrm{L}$ ascorbic acid, and $1 \mathrm{nmol} / \mathrm{L}$ selenium) for $24 \mathrm{~h}$. After $3 \mathrm{~h}$ of challenge with $200 \mu \mathrm{mol} / \mathrm{L} t$-BHP the neutral red assay was performed. Data are means + SEM of two independent experiments performed in duplicate. $\# p<0.01$; compared to control.

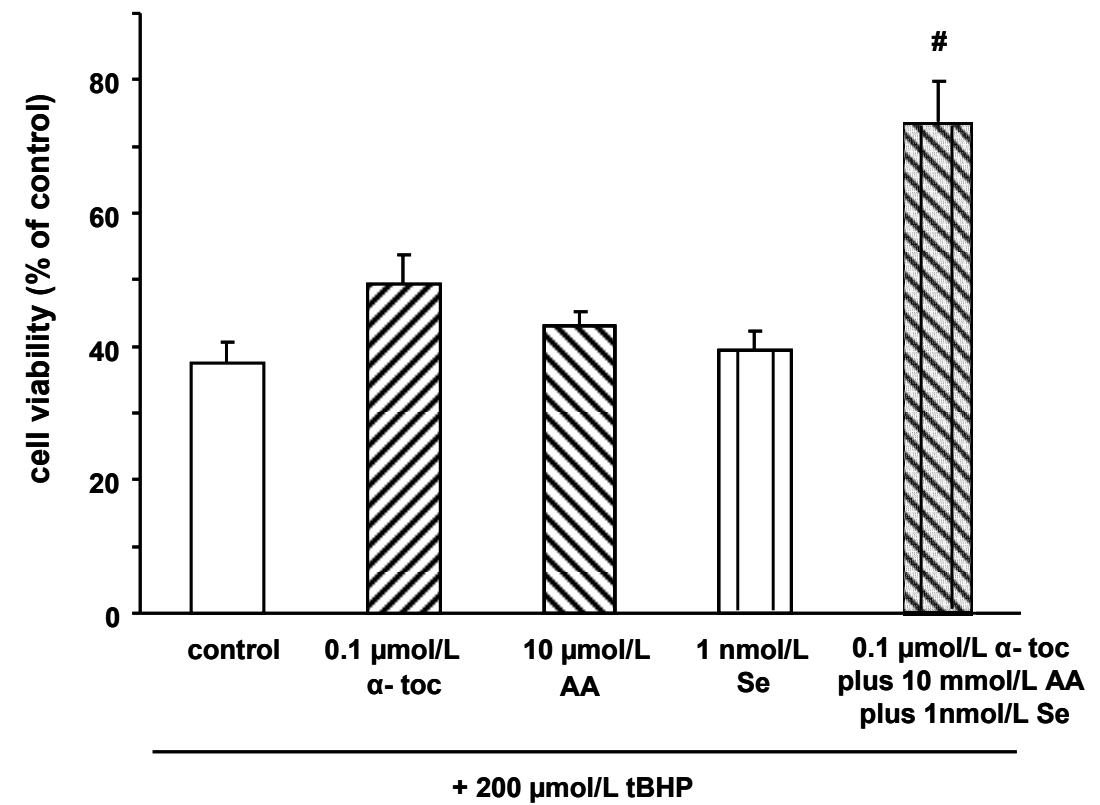

Table 1. Effect of $\alpha$-tocopherol, ascorbic acid and selenium on cell viability after challenge with increasing concentrations of $t$-BHP. Data are means \pm SEM and expressed in percentage of untreated control cells.

\begin{tabular}{|c|c|c|c|c|c|c|}
\hline \multirow[t]{2}{*}{$t$-BHP } & \multicolumn{2}{|c|}{$100 \mu \mathrm{mol} / \mathrm{L}$} & \multicolumn{2}{|c|}{$200 \mu \mathrm{mol} / \mathrm{L}$} & \multicolumn{2}{|c|}{$500 \mu \mathrm{mol} / \mathrm{L}$} \\
\hline & $\mathbf{M}$ & SEM & $\mathbf{M}$ & SEM & $\mathbf{M}$ & SEM \\
\hline Control & 49.7 & 4.0 & 37.6 & 3.2 & 31.4 & 1.2 \\
\hline \multirow{2}{*}{\multicolumn{7}{|c|}{$\begin{array}{l}\alpha \text {-Tocopherol (a-toc) } \\
\mu \mathrm{mol} / \mathrm{L}\end{array}$}} \\
\hline & & & & & & \\
\hline 0.1 & 65.4 & 5.4 & 49.3 & 4.6 & $36.4^{\mathrm{a}}$ & 1.6 \\
\hline 0.5 & $90.7^{\mathrm{c}}$ & 3.8 & $79.1^{\mathrm{c}}$ & 7.9 & $64.8^{\mathrm{c}}$ & 3.3 \\
\hline 2.5 & $92.8^{\mathrm{c}}$ & 3.2 & $89.7^{\mathrm{c}}$ & 1.4 & $83.9^{\mathrm{c}}$ & 7.5 \\
\hline \multicolumn{7}{|l|}{ Ascorbic acid (AA) } \\
\hline \multicolumn{7}{|l|}{$\mu \mathrm{mol} / \mathrm{L}$} \\
\hline 10 & 60.8 & 3.6 & 43.1 & 2.2 & 32.4 & 1.0 \\
\hline 25 & $78.2^{\mathrm{c}}$ & 2.6 & $59.6^{\mathrm{b}}$ & 4.1 & 36.1 & 0.7 \\
\hline 50 & $73.0^{\mathrm{b}}$ & 4.5 & $65.9^{\mathrm{c}}$ & 4.6 & $37.5^{\mathrm{a}}$ & 1.8 \\
\hline
\end{tabular}


Table 2. Cont.

\begin{tabular}{l}
\hline Selenium $(\mathrm{Se})$ \\
nmol/L \\
1 \\
10 \\
50
\end{tabular}

\section{Combinations}

I $(0.1 \mu \mathrm{mol} / \mathrm{L} \alpha$-toc, 10 $\mu \mathrm{mol} / \mathrm{L}$ AA, $1 \mathrm{nmol} / \mathrm{L}$ $\mathrm{Se})$

II $(0.1 \mu \mathrm{mol} / \mathrm{L} \alpha$-toc, $25 \mu \mathrm{mol} / \mathrm{L}$ AA, 10 $\mathrm{nmol} / \mathrm{L} \mathrm{Se})$

III $(0.1 \mu \mathrm{mol} / \mathrm{L} \alpha$-toc, $25 \mu \mathrm{mol} / \mathrm{L}$ AA, 25 $\mathrm{nmol} / \mathrm{L} \mathrm{Se})$

IV $(0.5 \mu \mathrm{mol} / \mathrm{L} \alpha$-toc, $25 \mu \mathrm{mol} / \mathrm{L} \mathrm{AA}, 10$ $\mathrm{nmol} / \mathrm{L} \mathrm{Se})$ $\mathbf{V}(0.1 \mu \mathrm{mol} / \mathrm{L} \alpha$-toc, $50 \mu \mathrm{mol} / \mathrm{L}$ AA, 50 $\mathrm{nmol} / \mathrm{L} \mathrm{Se})$

VI $(0.5 \mu \mathrm{mol} / \mathrm{L} \alpha$-toc, $50 \mu \mathrm{mol} / \mathrm{L}$ AA, 50 $\mathrm{nmol} / \mathrm{L} \mathrm{Se})$

VII $(2.5 \mu \mathrm{mol} / \mathrm{L} \alpha$-toc, $50 \mu \mathrm{mol} / \mathrm{L}$ AA, 50 $53.7 \quad 4.3$ $77.9^{\mathrm{b}} \quad 5.5$

$91.6^{\mathrm{c}} \quad 4.1$

$87.0^{\mathrm{c}} \quad 3.6$

$98.1^{\mathrm{c}} \quad 3.2$

$89.6^{\mathrm{c}}$

1.6

$69.0^{\mathrm{c}} \quad 4.6$

$100.6^{\mathrm{c}} \quad 1.2$

$95.2^{\mathrm{c}}$

2.4

$82.7^{\mathrm{c}} \quad 1.0$

$104.8^{\mathrm{c}} \quad 1.6$

$97.8^{c}$

2.8

$93.6^{\mathrm{c}} \quad 3.9$

$99.3^{\mathrm{c}} \quad 2.7$

$96.5^{\mathrm{c}} \quad 2.8$

$94.4^{\mathrm{c}} \quad 2.3$

$101.7^{\mathrm{c}} \quad 4.1$

$101.5^{\mathrm{c}} \quad 1.6$

$94.8^{\mathrm{c}}$

2.0

$103.0^{\mathrm{c}} \quad 1.2$

$98.9^{\mathrm{c}}$

2.9

$98.0^{\mathrm{c}} \quad 4.5$

${ }^{\mathrm{a}} p<0.05 ;{ }^{\mathrm{b}} p<0.01 ;{ }^{\mathrm{c}} p<0.001 ;$ different superscripts within a column indicate significant differences.

The protective effect of selenium on $t$-BHP-induced cell death in our chondrocyte model may be mediated due to the induction of the seleno-protein phospholipid-hydroperoxide glutathione peroxidase (PHGPx). PHGPx is an antioxidant seleno-protein known to directly reduce phospholipid hydroperoxides in membranes, thereby interacting synergistically with vitamin $\mathrm{E}$ [13].

Taken together current data in cultured chondrocytes indicate that $\alpha$-toc, AA, and Se do not work in isolation from each other and are rather part of an interacting set of redox-antioxidants [14]. As far as the concentration of the antioxidant nutrients are concerned, it needs to be taken into account that the concentrations of $\alpha$-toc $(0.1-2.5 \mu \mathrm{mol} / \mathrm{L})$, AA $(10-50 \mu \mathrm{mol} / \mathrm{L})$, and $\mathrm{Se}(1-50 \mathrm{nmol} / \mathrm{L})$, as used in this study, are by in large physiologically achievable [15-20]. However the plasma concentrations of glucosamine [21] and chondroitin [22] may be lower as compared to the concentrations as used in our cell culture model.

\section{3. $m R N A$ levels and secretion of matrix metalloproteinase-3}

Reactive oxygen species may serve as intracellular signalling molecules that amplify the synovial inflammatory response [10]. The pro-inflammatory cytokine IL-1 $\beta$, as used in our SW1353 cell culture 
model, initiates multiple intracellular events that ultimately result in the activation of proteinases including matrix metalloproteinase-3 [23]. In this context, it is suggested that SW1353 cells may be a valuable cellular model to study the induction of protease expression by inflammatory cytokines, a phenomenon which is also evident in primary chondrocytes [24]. SW1353 cells were treated with IL$1 \beta$ for 6,12 , and $24 \mathrm{~h}$ and MMP3 mRNA levels were determined by RT-PCR. MMP3 mRNA levels reached its maximum after $24 \mathrm{~h}$ of incubation (Figure 3), thus this time-point was selected for further MMP3 gene expression studies in the presence of the test compounds.

Figure 3. MMP3 mRNA levels in SW1353 cells following 6, 12, and $24 \mathrm{~h}$ of incubation with IL-1 $\beta$ (10 ng/mL). The highest induction of MMP3 was observed after $24 \mathrm{~h}$ of incubation. Results are calculated in relation to $\beta$-actin and expressed as means + SEM of three independent experiments performed in duplicate.

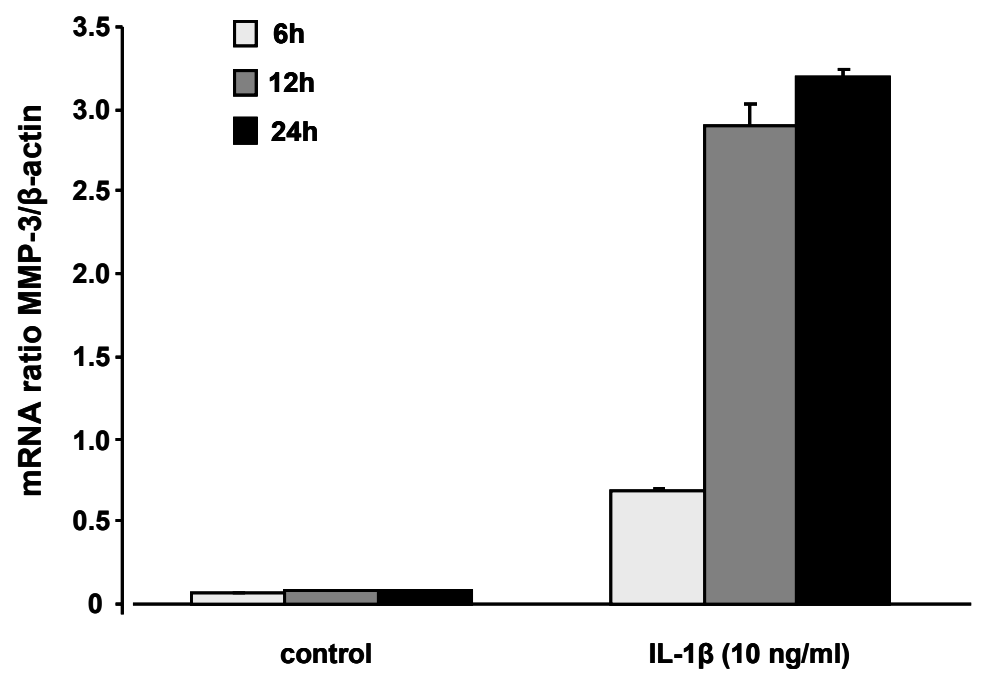

MMP3 is a membrane bound zinc anti-peptidase which degrades extra-cellular matrix [25]. Matrix metalloproteinase inhibitors have been proposed as potential therapeutic candidates in arthritis.

MMP3 mRNA levels were determined after co-incubation of IL-1 $\beta(10 \mathrm{ng} / \mathrm{mL})$ with GS, CS and the combination of GS and CS. Under the conditions investigated, CS was more potent than GS and the combination of GS and CS was more potent than CS only, in inhibiting IL-1 $\beta$-induced MMP3 gene expression (Figure 4A).

Differences in MMP3 gene expression in response to the treatments with GS and CS were also reflected on the protein level (Figure 4B). Again a combination of $500 \mu \mathrm{mol} / \mathrm{L}$ GS plus $500 \mu \mathrm{mol} / \mathrm{L}$ CS significantly decreased MMP3 secretion, whereas the single components resulted only in a moderate but not significant inhibition of IL-1 $\beta$-induced MMP3 secretion.

The induction of MMP3 can be counteracted by a combination of GS and CS more efficiently than by a single treatment with these test components. Thus, GS and CS act synergistically in inhibiting cytokine-induced MMP3 induction.

The underlying cellular and molecular mechanisms by which GS and CS may affect MMP3 have yet not been fully elucidated. Our data suggest that GS and CS affect MMP3 already on the transcriptional level which may in turn result in decreased MMP3 secretion. It has been suggested that 
GS may decrease the production of glycosylinositol phospholipid (GPI)-linked proteins which are crucial for the stimulation of chondrocytes by IL-1 $\beta[7,26]$.

Figure 4. Effect of glucosamine and chondroitin on MMP3 mRNA levels (A) and protein secretion (B) in IL-1 $\beta$ stimulated SW1353 cells. Cells were stimulated with IL-1 $\beta$ $(10 \mathrm{ng} / \mathrm{mL})$ in the presence of different concentrations of glucosamine, chondroitin and the combination of both test compounds for $24 \mathrm{~h}$. Cell culture supernatants were collected and the amount of MMP3 secreted by SW1353 cells was measured by specific ELISA. Results for MMP3 mRNA are calculated in relation to $\beta$-actin and compared to IL-1 $\beta$-treated cells. Data are means + SEM of three independent experiments performed in duplicate. $* p<0.05 ; \# p<0.01 ; \S p<0.001$; compared to IL-1 $\beta$.

A

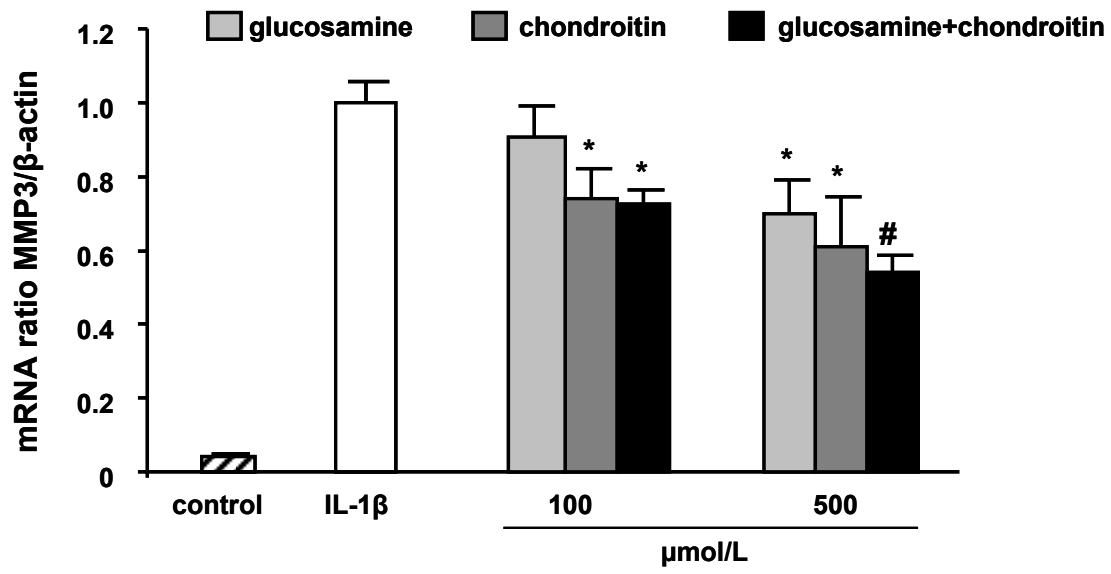

B

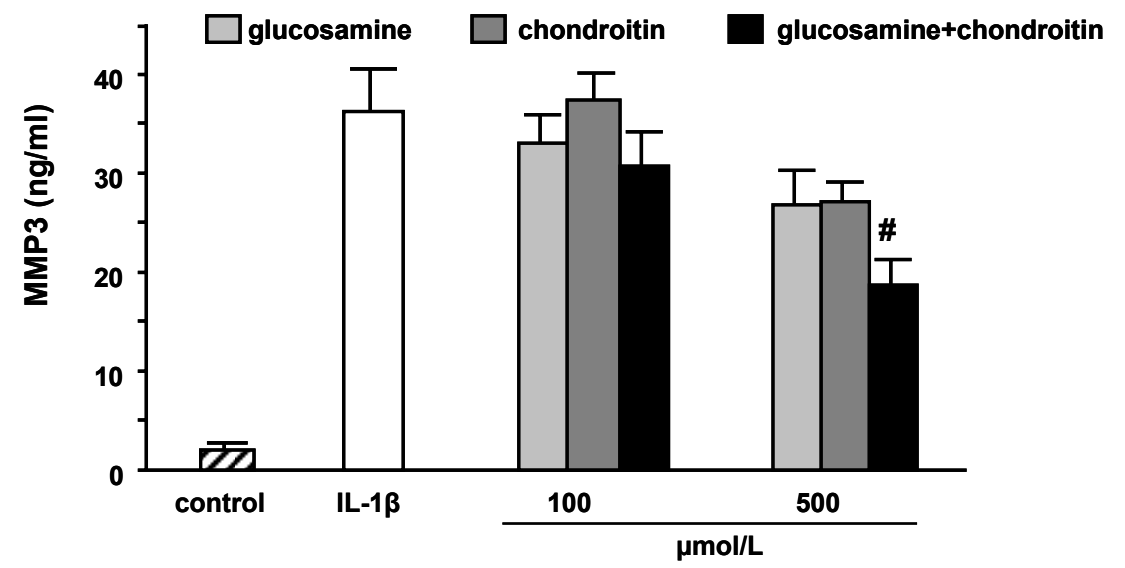

The relatively high concentration of GS which was necessary for the inhibition of MMP3 gene expression and secretion may be related to a competition between GS and glucose [present in high concentration in our cell culture medium $(4.5 \mathrm{~g} / \mathrm{L})$ ] for entering the chondrocytes via glucose

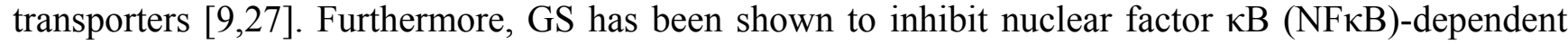
signal transduction pathway [28] which is involved in MMP3 upregulation [29]. Thus, antagonists of $\mathrm{NF} \kappa \mathrm{B}$ including GS may be effective inhibitors of the excessive destruction that is evident during chronic inflammatory conditions including oasteoarthritis [29].

Accordingly, it is suggested that CS may decrease NFאB nuclear translocation possibly by affecting extracellular signal-regulated kinase 1/2, p38mitogen-activated protein kinase and c-Jun N-terminal kinase activation [30]. Our results indicate that pre-treatment of SW1353 cells with $100 \mu \mathrm{mol} / \mathrm{L}$ GS 
and $100 \mu \mathrm{mol} / \mathrm{L} \mathrm{CS}$ resulted in a $20 \%$ inhibition of nuclear p65 protein levels, one subunit of NFkB (data not shown). Thus, GS and CS seem to address identical molecular targets which may explain their synergistic inhibitory activity on MMP3 gene expression and secretion. NFאB regulates TNF- $\alpha$ production in chondrocytes. TNF- $\alpha$ in turn stimulates the expression of MMP3 [31]. In the present study the inhibition of NFאB activity due to GS and CS was accompanied by a $30 \%$ decrease in TNF- $\alpha$ mRNA levels (data not shown) and TNF- $\alpha$ secretion as summarized in Figure 5. Again a combination of GS and CS was more potent than the single components per se.

Figure 5. Effect of glucosamine and chondroitin on TNF $\alpha$ protein secretion in IL-1 $\beta$ stimulated SW1353 cells. Cells were stimulated with IL-1 $\beta(10 \mathrm{ng} / \mathrm{mL})$ in the presence of $500 \mu \mathrm{mol} / \mathrm{L}$ of glucosamine, chondroitin and the combination of both test compounds for $24 \mathrm{~h}$. Cell culture supernatants were collected and the amount of TNF $\alpha$ secreted by SW1353 cells was measured by specific ELISA. Data are means + SEM of three independent experiments performed in duplicate. ${ }^{*} p<0.05$; compared to IL-1 $\beta$.

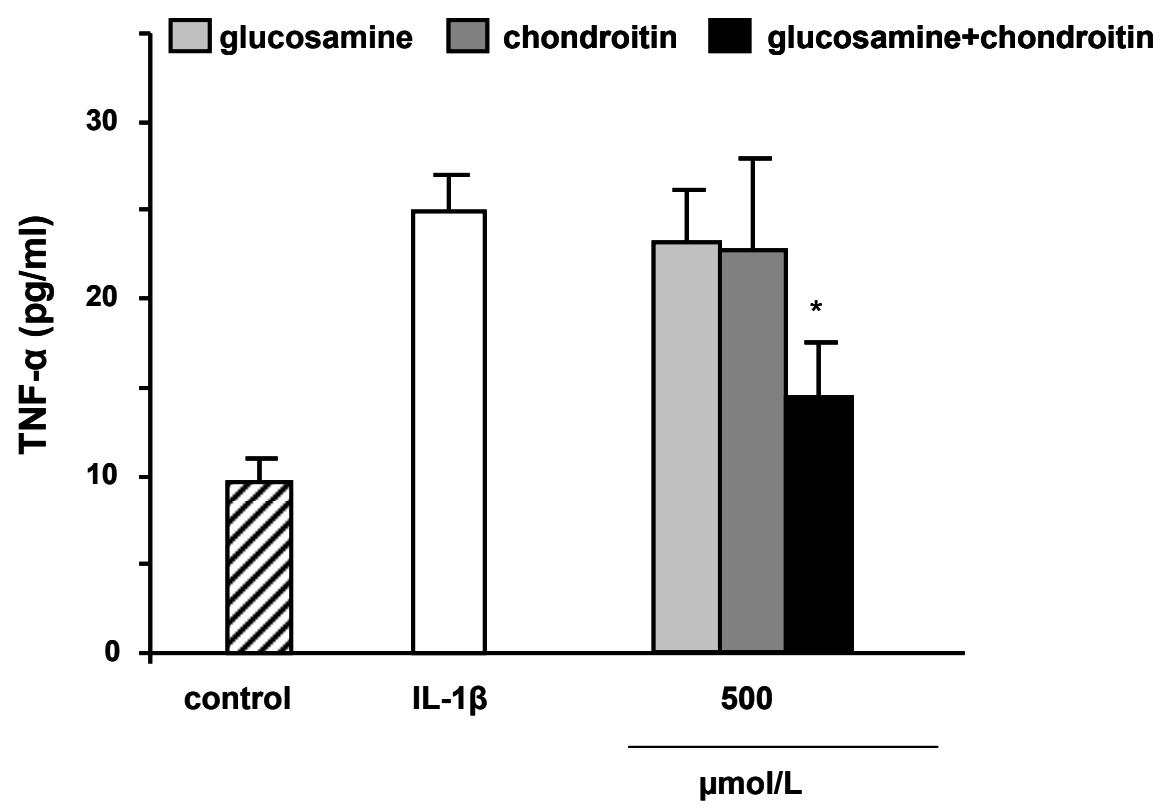

As far as MMP3 is concerned, it should be considered that in the present study only mRNA and protein levels of MMP3 have been determined. Thus, it needs to be studied in the future whether changes in MMP3 gene expression and secretion due to GS and CS are also reflected on the activity level. Whether the inhibition of MMP3 due to the combined application of GS and CS may result in changes in extracellular matrix production needs to be also studied in the future.

\section{Experimental}

\subsection{Cell culture}

SW1353 cells, a human chondrosarcoma cell line (I.A.Z., Munich, Germany), were grown in Dulbecco's modified eagle medium (DMEM) supplemented with $10 \%$ fetal bovine serum (FBS), $100 \mathrm{U} / \mathrm{mL}$ penicillin and $100 \mu \mathrm{g} / \mathrm{mL}$ streptomycin (all obtained from PAA Laboratories, Pasching, 
Austria). Cells were grown under standard conditions in a humidified incubator at $37{ }^{\circ} \mathrm{C}$ and $5 \% \mathrm{CO}_{2}$. The medium was replaced every second day. For experiments, cells were seeded at an initial densitiy of $5 \times 10^{3}$ cells $/ \mathrm{cm}^{2} 24 \mathrm{~h}$ before the start of experiments.

\subsection{Cytotoxicity studies}

Cytotoxicity of the test substances was evaluated by the neutral red assay [32,33]. Cells were treated with increasing concentrations of IL-1 $\beta$ (Invitrogen, Karlsruhe, Germany) (1, 10, and $100 \mathrm{ng} / \mathrm{mL})$, glucosamine and chondroitin $(100,500,750$, and $1000 \mu \mathrm{mol} / \mathrm{L})$. After $24 \mathrm{~h}$ incubation the medium was replaced by medium containing neutral red (3-amino- $m$-dimethylamino-2methylphenazine hydrochloride, DMEM, $50 \mu \mathrm{g} / \mathrm{mL}$; Carl Roth, Karlsruhe, Germany) and cells were incubated for $3 \mathrm{~h}$. The neutral red dye was extracted by a bleaching solution containing $50 \%$ ethanol, $1 \%$ acetic acid and $49 \% \mathrm{H}_{2} \mathrm{O}$. Absorbance was read at $540 \mathrm{~nm}$ (Labsystems iEMS Reader MF, Labsystems, Finland) and cell viability was calculated as percentage of medium treated control cells. In a second set of experiments the impact of the antioxidants ascorbic acid, $\alpha$-tocopherol, and selenium (alone and in combination) on tert-butyl hydroperoxide ( $t$-BHP)-induced cell death was studied. SW1353 cells were incubated with increasing non-cytotoxic concentrations of ascorbic acid $(0,10,25$, and $50 \mu \mathrm{mol} / \mathrm{L}$; Carl Roth, Karlsruhe, Germany), $\alpha$-tocopherol (0, 0.1, 0.5, $2.5 \mu \mathrm{mol} / \mathrm{L}$; BASF, Ludwigshafen, Germany) and selenium (0, 1, 10, $50 \mathrm{nmol} / \mathrm{L}$; Sigma-Aldrich, Munich, Germany) (single substances and combinations) for $24 \mathrm{~h}$. $t$-BHP (Acros Organics, NJ, USA) was added in different concentrations $(0,100,200$, and $500 \mu \mathrm{mol} / \mathrm{L})$ for $3 \mathrm{~h}$ to induce cell damage/death and cell viability was determined by neutral red assay.

\subsection{Matrix metalloproteinase-3 and tumor necrosis factor alpha gene expression and secretion}

RNA isolation and real time PCR measurements

Cells were co-incubated with IL-1 $\beta(10 \mathrm{ng} / \mathrm{mL})$ and 100 and $500 \mu \mathrm{mol} / \mathrm{L}$ glucosamine sulfate, chondroitin sulfate (Bayer AG, Leverkusen, Germany) or the combination of both (100 and $500 \mu \mathrm{mol} / \mathrm{L}$ of each test compound). After 6,12 , and $24 \mathrm{~h}$ the medium was collected and the cells were lysed by TRIsure reagent (Bioline, London, United Kingdom) according to the manufacturer's protocol. The concentration of RNA was determined by measuring the absorbance at $260 \mathrm{~nm}$. The purity was determined by the ratio of $260 / 280 \mathrm{~nm}$ using a spectrophotometer (Beckman Coulter $\mathrm{GmbH}$, Munich, Germany). RNA concentration was diluted to $100 \mathrm{ng} / \mu \mathrm{L}$ and aliquots were stored at $80{ }^{\circ} \mathrm{C}$ until PCR analysis. Real-time quantitative PCR was performed in a Rotor Gene 6000 thermocycler (Corbett Research, Sydney, Australia) and carried out using the SensiMix ${ }^{\mathrm{TM}}$ One-Step Kit with SybrGreen detection (Quantance, Berlin, Germany) according to the manufacturer's instructions. Primer sequences for $\beta$-actin, MMP3 and TNF $\alpha$ are summarized in Table 2 below. mRNA levels of MMP3 and TNF $\alpha$ were related to the house-keeping gene $\beta$-actin. 
Table 3. Primer sequences and conditions for real time PCR experiments.

\begin{tabular}{lll}
\hline Gene & Sequence $\left(\mathbf{5}^{\prime} \mathbf{-} \mathbf{3}^{\prime}\right)$ & $\begin{array}{l}\text { Annealing } \\
\text { temperature }\end{array}$ \\
\hline b-actin & F: GGA TGC AGA AGG AGA TCA CTG & $55^{\circ} \mathrm{C}$ \\
& R: CGA TCC ACA CGC AGT ACT TG & \\
MMP3 & F: TTT TGG CCA TCT CTT CCT TCA & $59^{\circ} \mathrm{C}$ \\
& R: TGT GGA TGC CTC TTG GGT ATC & \\
TNF- $\alpha$ & F: CCC CAG GGA CCT CTC TCT A & $60^{\circ} \mathrm{C}$ \\
& R: GGT TTG CTA CAA CAT GGG CTA CA & \\
\hline
\end{tabular}

\subsection{MMP3 and TNF $\alpha$ quantification by ELISA}

Secretion of MMP3 and TNF $\alpha$ was determined in all culture supernatants using a commercial ELISA kit (DuoSet ${ }^{\circledR}$ ELISA Development System, R\&D Systems, Inc. Wiesbaden, Germany) according to the manufacturer's protocol. Optical density readings at $450 \mathrm{~nm}$ were performed using a microplate reader (Tecan Germany GmbH, Crailsheim, Germany).

\subsection{Western blot analysis for p65}

Following pre-treatment with test compounds for $1.5 \mathrm{~h}$ cells were co-incubated with IL-1 $\beta$ for $3 \mathrm{~h}$. Subsequently, cells were washed with ice-cold PBS, scraped and centrifuged $\left(800 \times g, 4{ }^{\circ} \mathrm{C}, 3 \mathrm{~min}\right)$. After discarding the supernatant, the remaining cell pellet was carefully resuspended in $100 \mu 1$ of ice-cold buffer A $[10 \mathrm{mmol} / \mathrm{L}$ HEPES (pH 7.9), $10 \mathrm{mmol} / \mathrm{L} \mathrm{KCl}, 1.5 \mathrm{mmol} / \mathrm{L} \mathrm{MgCl} 2,0.5 \mathrm{mmol} / \mathrm{L}$ DTT, 0.1\%, Nonidet-P40, protease inhibitor cocktail (Sigma)], and incubated on ice for $15 \mathrm{~min}$. Afterwards, the homogenates were centrifuged $\left(4,000 \mathrm{xg}, 4{ }^{\circ} \mathrm{C}, 1 \mathrm{~min}\right)$ and the supernatants were removed. The pellets were resuspended in $80 \mu \mathrm{L}$ of ice-cold buffer B [40 mmol/L HEPES (pH 7.9), $400 \mathrm{mmol} / \mathrm{L} \mathrm{KCl}, 1 \mathrm{mmol} / \mathrm{L} \mathrm{DTT}, 6.25 \% 5 \mathrm{M} \mathrm{NaCl}, 10 \%$ glycerol and protease inhibitors], left on ice for $30 \mathrm{~min}$ and centrifuged $\left(18,000 \mathrm{xg}, 4^{\circ} \mathrm{C}\right)$ for $30 \mathrm{~min}$. Supernatants (nuclear extracts) were removed and stored at $-80^{\circ} \mathrm{C}$ until further analysis [34].

Protein concentrations were determined by BCA protein assay (Pierce, Rockford, USA). A quantity of protein of each sample $(40 \mu \mathrm{g})$ was mixed with loading buffer, denatured at $95{ }^{\circ} \mathrm{C}$ for 5 min and separated on a $12 \%$ SDS-PAGE. Subsequently, the samples were transferred onto a polyvinylidene fluoride (PVDF) membrane and blocked with 5\% skim milk dissolved in TBS $+0.05 \%$ Tween-20 (TBST) for a minimum of $1 \mathrm{~h}$. The membrane was probed with the respective antibody (p65: 1:500; actin: 1:800) (Santa Cruz Biotechnology, Heidelberg, Germany) at $4{ }^{\circ} \mathrm{C}$ overnight. Afterwards the membrane was washed and incubated with the respective HRP-conjugated secondary antibody (antirabbit: 1:4,000) for $50 \mathrm{~min}$. The protein bands were visualized using Pierce ${ }^{\circledR}$ ECL Western Blotting Substrate kit (Pierce) in a ChemiDoc XRS system (BioRad, Munich, Germany). Relative intensities of the bands were quantified by densitometry and expressed as ratio between target protein (p65) and loading control (actin). 


\subsection{Statistical analysis}

Results are expressed as mean values with SEM. Data were tested for normal distribution and analyzed by posthoc test (Dunnett following ANOVA) or by $t$-test. In the case of non-parametric data the Mann-Whitney $U$-test was applied. Differences were considered significant when the $p$ value was $\leq 0.05$. Statistical analyses calculations were performed with SPSS Version 15.0.

\section{Conclusions}

Overall our results suggest that combining natural compounds such as $\alpha$-toc, AA, and Se as well as GS and CS seems to be a promising strategy to combat oxidative stress and cytokine induced matrix degradation in cultured chondrocytes. The in vitro data regarding the synergistic antioxidant activity of $\alpha$-toc, AA, and Se as well as the synergistic inhibitory activity of GS and CS on MMP3 levels and TNF- $\alpha$ secretion need to be validated in vivo.

\section{References}

1. Pattoli, M.A.; MacMaster, J.F.; Gregor, K.R.; Burke, J.R. Collagen and aggrecan degradation is blocked in interleukin-1-treated cartilage explants by an inhibitor of IkappaB kinase through suppression of metalloproteinase expression. J. Pharmacol. Exp. Ther. 2005, 315, 382-388.

2. Choi, E.J.; Bae, S.C.; Yu, R.; Youn, J.; Sung, M.K. Dietary vitamin E and quercetin modulate inflammatory responses of collagen-induced arthritis in mice. J. Med. Food. 2009, 12, 770-775.

3. Kurz, B.; Jost, B.; Schünke M. Dietary vitamins and selenium diminish the development of mechanically induced osteoarthritis and increase the expression of antioxidative enzymes in the knee joint of STR/1N mice. Osteoarth. Cartilage 2002, 10,119-126.

4. van Vugt, R.M.; Rijken, P.J.; Rietveld, A.G.; van Vugt, A.C.; Dijkmans, B.A. Antioxidant intervention in rheumatoid arthritis: Results of an open pilot study. Clin. Rheumatol. 2008, 27, 771-775.

5. Bae, S.C.; Kim, S.J.; Sung, M.K. Inadequate antioxidant nutrient intake and altered plasma antioxidant status of rheumatoid arthritis patients. J. Am. Coll. Nutr. 2003, 22, 311-315.

6. Wang, Y.; Hodge, A.M.; Wluka, A.E.; English, D.R.; Giles, G.G.; O'Sullivan, R.; Forbes, A.; Cicuttini, F.M. Effect of antioxidants on knee cartilage and bone in healthy, middle-aged subjects: A cross-sectional study. Arthritis Res. Ther. 2007, 9, R66.

7. Dodge, G.R.; Jimenez, S.A. Glucosamine sulfate modulates the levels of aggrecan and matrix metalloproteinase-3 synthesized by cultured human osteoarthritis articular chondrocytes. Osteoarth. Cartilage 2003, 11, 424-432.

8. Legendre, F.; Baugé, C.; Roche, R.; Saurel, A.S.; Pujol, J.P. Chondroitin sulfate modulation of matrix and inflammatory gene expression in IL-1beta-stimulated chondrocytes--study in hypoxic alginate bead cultures. Osteoarth. Cartilage 2008, 16, 105-114.

9. Shikhman, A.R.; Kuhn, K.; Alaaeddine, N.; Lotz, M. N-acetylglucosamine prevents IL-1 betamediated activation of human chondrocytes. J. Immunol. 2001, 166, 5155-5160.

10. Hitchon, C.A.; El-Gabalawy, H.S. Oxidation in rheumatoid arthritis. Arthritis Res. Ther. 2004, 6, $265-278$. 
11. Packer, L.; Weber, S.U.; Rimbach, G. Molecular aspects of alpha-tocotrienol antioxidant action and cell signalling. J. Nutr. 2001, 131, 369-373.

12. Rimbach, G.; Minihane, A.M.; Majewicz, J.; Fischer, A.; Pallauf, J.; Virgli, F.; Weinberg, P.D. Regulation of cell signalling by vitamin E. Proc. Nutr. Soc. 2002, 61, 415-425.

13. Ursini, F.; Maiorino, M.; Roveri, A. Phospholipid hydroperoxide glutathione peroxidase (PHGPx): More than an antioxidant enzyme? Biomed. Environ. Sci. 1997, 10, 327-332.

14. Fischer, A.; Pallauf, J.; Gohil, K.; Weber, S.U.; Packer, L.; Rimbach, G. Effect of selenium and vitamin E deficiency on differential gene expression in rat liver. Biochem. Biophys. Res. Commun. 2001, 285, 470-475.

15. Allen, N.E.; Appleby, P.N.; Roddam, A.W.; Tjønneland, A.; Johnsen, N.F.; Overvad, K.; Boeing, H.; Weikert, S.; Kaaks, R.; Linseisen, J.; Trichopoulou, A.; Misirli, G.; Trichopoulos, D.; Sacerdote, C.; Grioni, S.; Palli, D.; Tumino, R.; Bueno-de-Mesquita, H.B.; Kiemeney, L.A.; Barricarte, A.; Larrañaga, N.; Sánchez, M.J.; Agudo, A.; Tormo, M.J.; Rodriguez, L.; Stattin, P.; Hallmans, G.; Bingham, S.; Khaw, K.T.; Slimani, N.; Rinaldi, S.; Boffetta, P.; Riboli, E.; Key, T.J. Plasma selenium concentration and prostate cancer risk: Results from the European Prospective Investigation into Cancer and Nutrition (EPIC). Am. J. Clin. Nutr. 2008, 88, 1567-1575.

16. Bader, N.; Bosy-Westphal, A.; Koch, A.; Rimbach, G.; Weimann, A.; Poulsen, H.E.; Müller, M.J. Effect of hyperbaric oxygen and vitamin $\mathrm{C}$ and $\mathrm{E}$ supplementation on biomarkers of oxidative stress in healthy men. Br. J. Nutr. 2007, 98, 826-833.

17. Behrens, W.A.; Madere, R. Alpha- and gamma tocopherol concentrations in human serum. J. Am. Coll. Nutr. 1986, 5, 91-96.

18. Majewicz, J.; Rimbach, G.; Proteggente, A.R.; Lodge, J.K.; Kraemer, K.; Minihane, A.M. Dietary vitamin $\mathrm{C}$ down-regulates inflammatory gene expression in apoE4 smokers. Biochem. Biophys. Res. Commun. 2005, 338, 951-955.

19. Proteggente, A.R.; Rota, C.; Majewicz, J.; Rimbach, G.; Minihane, A.M.; Kramer, K.; Lodge, J.K. Cigarette smokers differ in their handling of natural (RRR) and synthetic (all rac) alphatocopherol: A biokinetik study in apoE4 male subjects. Free Radic Biol. Med. 2006, 40, 2080-2091.

20. Schleicher, R.L.; Carroll, M.D.; Ford, E.S.; Lacher, D.A. Serum vitamin C and the prevalence of vitamin C deficiency in the United States: 2003-2004 National Health and Nutrition Examination Survey (NHANES). Am. J. Clin. Nutr. 2009, 90, 1252-1263.

21. Persiani, S.; Roda, E.; Rovati, L.C.; Locatelli, M.; Giacovelli, G.; Roda, A. Glucosamine oral bioavailability and plasma pharmacokinetics after increasing doses of crystalline glucosamine sulfate in man. Osteoarth. Cartilage 2005, 13, 1041-1049.

22. Volpi, N. Oral bioavailability of chondroitin sulfate (Condrosulf) and its constituents in healthy male volunteers. Osteoarth. Cartilage 2002, 10, 768-777.

23. Daheshia, M.; Yao, J.Q. The interleukin 1beta pathway in the pathogenesis of osteoarthritis. $J$. Rheumatol. 2008, 35, 2306-2312.

24. Gebauer, M.; Saas, J.; Sohler, F.; Haag, J.; Söder, S.; Pieper, M.; Bartnik, E.; Beninga, J.; Zimmer, R.; Aigner, T. Comparison of the chondrosarcoma cell line SW1353 with primary human 
adult articular chondrocytes with regard to their gene expression profile and reactivity to IL1 beta. Osteoarth. Cartilage 2005, 13, 697-708.

25. Murphy, G.; Nagase, H. Progress in matrix metalloproteinase research. Mol. Aspects Med. 2008, 29, 290-308.

26. Sandy, J.D.; Thompson, V.; Verscharen, C.; Gamett, D. Chondrocyte-mediated catabolism of aggrecan: Evidence for a glycosylphosphatidylinositol-linked protein in the aggrecanase response to interleukin-1 or retinoic acid. Arch. Biochem. Biophys. 1999, 367, 258-264.

27. Rauchman, M.I.; Wasserman, J.C.; Cohen, D.M.; Perkins, D.L.; Hebert, S.C.; Milford, E.; Gullans, S.R. Expression of GLUT-2 cDNA in human B lymphocytes: Analysis of glucose transport using flow cytometry. Biochim. Biophys. Acta 1992, 1111, 231-238.

28. Gouze, J.N.; Bianchi, A.; Bécuwe, P.; Dauça, M.; Netter, P.; Magdalou, J.; Terlain, B.; Bordji, K. Glucosamine modulates IL-1-induced activation of rat chondrocytes at a receptor level, and by inhibiting the NF-kappa B pathway. FEBS Lett. 2002, 510, 166-170.

29. Bond, M.; Baker, A.H.; Newby, A.C. Nuclear factor kappaB activity is essential for matrix metalloproteinase-1 and -3 upregulation in rabbit dermal fibroblasts. Biochem. Biophys. Res. Commun. 1999, 264, 561-567.

30. Iovu, M.; Dumais, G.; du Souich, P. Anti-inflammatory activity of chondroitin sulfate. Osteoarth. Cartilage 2008, 16, 14-18.

31. Klatt, A.R.; Klinger, G.; Paul-Klausch, B.; Kühn, G.; Renno, J.H.; Wagener, R.; Paulsson, M.; Schmidt, J.; Malchau, G.; Wielckens, K. Matrilin-3 activates the expression of osteoarthritisassociated genes in primary human chondrocytes. FEBS Lett. 2009, 583, 3611-3617.

32. Borenfreund, E.; Puerner, J.A. Toxicity determined in vitro by morphological alterations and neutral red absorption. Toxicol Lett. 1985, 24, 119-124.

33. Valacchi, G.; Rimbach, G.; Saliou, C.; Weber, S.U.; Packer, L. Effect of benzoyl peroxide on antioxidant status, NF-kappaB activity and interleukin-1alpha gene expression in human keratinocytes. Toxicology 2001, 165, 225-234.

34. Wagner, A.E.; Ernst, I.; Iori, R.; Desel, C.; Rimbach, G. Sulforaphane but not ascorbigen, indole3 -carbinole and ascorbic acid activates the transcription factor Nrf2 and induces phase-2 and antioxidant enzymes in human keratinocytes in culture. Exp. Dermatol. 2009, [Epub ahead of print].

Sample Availability: Contact the authors.

(C) 2010 by the authors; licensee Molecular Diversity Preservation International, Basel, Switzerland. This article is an open-access article distributed under the terms and conditions of the Creative Commons Attribution license (http://creativecommons.org/licenses/by/3.0/). 